Latin and Vernacular in Quattrocento Florence and Beyond: An Introduction Author(s): Andrea Rizzi and Eva Del Soldato

Source: I Tatti Studies in the Italian Renaissance, Vol. 16, No. $1 / 2$ (September 2013), pp. $231-242$

Published by: The University of Chicago Press on behalf of Villa I Tatti, The Harvard Center for Italian Renaissance Studies

Stable URL: https://www.jstor.org/stable/10.1086/673422

JSTOR is a not-for-profit service that helps scholars, researchers, and students discover, use, and build upon a wide range of content in a trusted digital archive. We use information technology and tools to increase productivity and facilitate new forms of scholarship. For more information about JSTOR, please contact support@jstor.org.

Your use of the JSTOR archive indicates your acceptance of the Terms \& Conditions of Use, available at https://about.jstor.org/terms

The University of Chicago Press and Villa I Tatti, The Harvard Center for Italian Renaissance Studies are collaborating with JSTOR to digitize, preserve and extend access to I Tatti Studies in the Italian Renaissance 


\title{
Latin and Vernacular in Quattrocento Florence and Beyond: An Introduction
}

\author{
Andrea Rizzi, University of Melbourne \\ Eva Del Soldato, University of Pennsylvania
}

THIS CLUSTER EXPLORES the interaction between language and its sociocultural use in quattrocento Florence. This has entailed a bottom-up view of the use and understanding of Latin and the volgare at a time when humanists were refashioning classical Latin into a powerful cultural and political tool. ${ }^{1}$ All contributions take a close look at what quattrocento authors, translators, and speakers say about their choices to perform their texts in Latin or vernacular and how they perceived and represented these languages. Clearly, these early modern multilingual communicators appreciated the power of language and its inherently social dimension. More important, they understood the social meaning and value of their plurilingualism. ${ }^{2}$ The humanists' effort to transform Ciceronian Latin into a highly prestigious and influential language captivated several quattrocento rulers (most notably Federico da Montefeltro, Leonello d'Este, and Filippo Maria Visconti) and high-ranking members of courtly and mercantile societies, who followed their studia humanitatis. ${ }^{3}$ This impression has overshadowed in many aspects the

Contact Andrea Rizzi at the School of Languages and Linguistics, Babel Building 504, University of Melbourne, Parkville VIC 3055, Australia (arizzi@unimelb.edu.au). Contact Eva Del Soldato at the University of Pennsylvania, Center for Italian Studies, 534 Williams Hall, 255 South 36th Street, Philadelphia, PA 19104 (evadel@sas.upenn.edu).

1. A similar approach has been taken by Pietro Trifone, Rinascimento dal basso: Il nuovo spazio del volgare tra Quattro e Cinquecento (Rome, 2006).

2. See Peter Burke and Roy Porter, eds., The Social History of Language (Cambridge, 1987).

3. See Coluccio Salutati in his De Fato (ca. 1396): "Nam cum sicut difficillimum sit latinitatis elegantiam in vulgare quoppiam transferendo servare, sic etiam et e contra vulgare quamvis mediocriter cultum nunquam vertatur in latinum servando parem ornatum" (As it is extremely difficult to retain the elegance of Latin in a translation into whatever vernacular, even a moderately elegant form of vernacular will not retain equal beauty when translated into Latin). Coluccio Salutati, De fato et fortuna, ed. Concetta Bianca (Florence, 1985), 193. English translation by Andrea Rizzi.

I Tatti Studies in the Italian Renaissance, volume 16, number 1/2. @ 2013 by Villa I Tatti: The Harvard University Center for Italian Renaissance Studies. All rights reserved. 0393-5949/2013/1612-0005\$10.00 
vernacular works of first-rank humanists, sometimes leading to the simple but mistaken conclusion that the quattrocento was not the century of the vernacular. ${ }^{4}$ As a result, it is generally believed that the first age of vernacularization ended at the turn of the fifteenth century, when scholars turned to the original Latin and Greek texts in order to acquire a greater understanding of classical and medieval culture. Instead, this volume demonstrates that scholarship in the quattrocento was not divided between Latin and vernacular humanism but thrived precisely because of its linguistic versatility and interaction.

Furthermore, the following essays aim to reveal the role given in quattrocento Florence and Venice to Latin and the vernacular, exploring the place these languages occupied in the literary and social spaces of the fifteenth century as well as the cultural and political motivations informing linguistic choices. The picture that will emerge from the contributions to this cluster is one in which Latin and vernacular were not seen as in conflict but were given different and complementary roles and spaces. As Brian Maxson and Andrea Rizzi demonstrate in this volume, the enduring understanding that a divide existed in quattrocento Italy between vernacular and "low" or popular literature, on the one hand, and Latin and texts of elevated discourse, on the other, needs to be reassessed: quattrocento humanists such as Bruni read, wrote, and supported the production of vernacular texts.

The suitability of the vernacular for the translation and dissemination of technical subjects in both oral and written contexts represents another important focus of the current volume. As Elizabeth Mellyn reveals, the dialectic between Latin and vernacular is enriched in scientific texts, such as physiognomy and philosophy, by the unavoidable shifting of meaning occurring in the translation process. As a result, the study of prefaces and similar paratextual material presents scholars with compelling evidence of how quattrocento authors and translators engaged with Latin and vernacular texts and audiences. Translation is the key locus

4. See, e.g., Vittorio Formentin, "La 'crisi' linguistica del Quattrocento," in Storia della Letteratura Italiana, ed. Enrico Malato (Rome, 1996), 3:159-210, 169: "Quanto alle traduzioni dal latino, ben si capisce che la pratica dei volgarizzamenti sia stata estranea alla cultura umanistica: più esplicitamente, il volgarizzamento di un testo classico non era un'operazione umanisticamente giustificabile." A similar view is expressed in Ronald G. Witt, In the Footsteps of the Ancients: The Origins of Humanism from Lovato to Bruni (Leiden, 2000), 229. For a critique of this oppositional understanding of the relationship between Latin and vernacular cultures during the quattrocento, see Giancarlo Mazzacurati, Il Rinascimento dei moderni: La crisi culturale del XVI secolo e la negazione delle origini (Bologna, 1985); Rossella Bessi, Umanesimo volgare: Studi di letteratura fra Tre e Quattrocento (Florence, 2004); and James Hankins, "Humanism in the Vernacular: The Case of Leonardo Bruni," in Humanism and Creativity in the Renaissance: Essays in Honor of Ronald G. Witt, ed. Christopher S. Celenza and Kenneth Gouwens (Leiden, 2006), 11-29. 
of exchange between vernacular and Latin ideas and practices and, as Eugenio Refini demonstrates, offered an extraordinarily productive platform for the interaction of scholastic and humanistic trends in both Latin and vernacular philosophical texts. Further, Eva Del Soldato shows how an influential Platonist such as Cattani da Diacceto believed that Latin was not superior to the vernacular but that the elegant use of either language could befit writing on highly specialized disciplines such as philosophy. Latin is not superior to the vernacular. Instead, both languages can express the most complex concepts when they are used by highly trained and learned authors.

Written texts, in both Latin and vernacular, were also translated into permeable and ubiquitous oral texts. The oral environment of quattrocento Florence was a complex space in which the city's ideas, values, and attitudes were expressed through mostly vernacular performances by preachers, poets, storytellers, musicians, and singers. Blake Wilson's essay reveals how the oral and live performances in the Florentine piazza of San Martino constantly reinvented the relationship between writing and orality, Latin and vernacular, different textual genres and the varied ranks of society. These performances, as Wilson demonstrates, were enjoyed not only by the illiterate but also by Latin scholars such as Michele Verino.

By way of introducing the following essays, we will briefly explore how the humanists of early quattrocento Italy debated, perceived, and performed the interactions between these languages. We will also engage with recent literature on quattrocento humanism and call for a stronger focus on orality and the varied reception and transmission of Greek and Latin by merchants, low-rank politicians and officers, and non-Latinate scholars.

\section{THE 1435 DEBATE: FLORENCE AND BEYOND}

The relationship between the vernacular languages and Latin was debated ardently by early quattrocento humanists such as Biondo Flavio, Leonardo Bruni, Poggio Bracciolini, and Lorenzo Valla. ${ }^{5}$ Set in early 1435 Florence, at the center

5. There is an extensive bibliography on the 1435 debate on Latin and its relationship with the vernaculars, which will be discussed below. The works that have been most relevant to the current study are Donatella Coppini, "Il cielo della luna: Alcune considerazioni su grammatica e latino in età medievale e umanistica," Rinascimento 27 (1987): 179-214; Mirko Tavoni, Latino, grammatica, volgare: Storia di una questione umanistica (Padua, 1984); Silvia Rizzo, "Il Latino nell'umanesimo," in Letteratura Italiana, ed. Asor Rosa (Turin, 1986), 5:379-408, and Ricerche sul latino umanistico (Rome, 2002); Witt, In the Footsteps; Christopher Celenza, "End Game: Humanist Latin in the Fifteenth Century," in Latinitas Perennis II: Appropriation and Latin Literature, ed. Y. Maes, J. Papy, and W. Verbaal (Leiden, 2009), 201-42; Hankins, "Humanism," 19-20; Angelo Mazzocco, Linguistic 
of the debate was classical Latin and its perceived prestige and importance in the cultural milieus of the Italian and European Renaissance centers of learning. In general terms, the main concern shared by humanists was the nature of the Latin language. Most agreed that Latin was a medium created artificially and therefore best suited to intellectually sophisticated communication and exchange. The use of the word gramatica to describe Latin and its normative nature-an ars, with a clearly and intricately built morphology and syntax-reveals an understanding of Latin and the other artificial languages (Greek, Hebrew, but also Arabic and Chaldaic) radically different from that of the vernacular languages. By stressing the grammaticality of Latin, the humanists noted the perceived lack of stability and structure in the vernacular tongues. Some of these scholars saw the vernaculars as having existed before Latin was literally invented (see Dante's three phases of the creation of Latin in his De Vulgari Eloquentia). ${ }^{6}$ Others believed the vernaculars to have developed after the demise of the Roman empire and its linguistic hegemony. What almost all humanists of early quattrocento Italy agreed on was the conviction that Latin was the most suitable medium for written and learned culture because of its stability and artificiality. Latin had been created by ancient auctores who offered scholars clearly defined models and examples that could be studied and practiced through the trivium (grammar, logic, and rhetoric). ${ }^{7}$ It was firmly believed that the philological study of these ancient models allowed the restoration of classical Latin and the heightening of the Latin culture that had been "silent, maimed and weak" for centuries. ${ }^{8}$

The humanists of early quattrocento Italy agreed on the nature, role, and identity of the Latin language. At the same time, they had very different views on

Theories in Dante and the Humanists: Studies of Language and Intellectual History in Late Medieval and Early Renaissance Italy (Leiden, 1993); Simon A. Gilson, Dante and Renaissance Florence, pt. 2 (Cambridge, 2005); Riccardo Fubini, Umanesimo e secolarizzazione da Petrarca a Valla (Rome, 1990), 1-75; Christopher Celenza, The Lost Italian Renaissance: Humanists, Historians, and Latin's Legacy (Baltimore, 2004); and Stephen Milner, "'Le sottili cose non si possono bene aprire in volgare': Vernacular Oratory and the Transmission of Classical Rhetorical Theory in the Late Medieval Italian Communes," Italian Studies 64 (2009): 221-44.

6. See Mazzocco, Linguistic Theories, chap. 2; the recent Mirko Tavoni, "Volgare e latino nella storia di Dante," in Dante's Plurilingualism: Authority, Knowledge, Subjectivity, ed. Sara Fortuna, Manuele Grignolati, and Jürgen Trabant (Leeds, 2010), 52-68; and Jürgen Trabant, "Millena Variatio: Overcoming the Horror of Variation," in ibid., 24-33.

7. On humanistic pedagogy and the formation of the humanist, see Robert Black, Humanism and Education in Medieval and Renaissance Italy: Tradition and Innovation in Latin Schools from the Twelfth to the Fifteenth Century (Cambridge, 2001); Paul F. Grendler, Schooling in Renaissance Italy: Literacy and Learning, 1300-1600 (Baltimore, 1989); James M. Murphy, Latin Rhetoric and Education in the Middle Ages and Renaissance (Hampshire, 2005); Craig Kallendorf, Humanist Educational Treatises (Cambridge, MA, 2002); and Witt, In the Footsteps.

8. This is how Poggio Bracciolini describes the period before the humanistic discovery of and interest in Greek letters as a way to reform the Latin language and culture. See Witt, In the Footsteps, 342. 
the relationship between Latin and the vernaculars and, most important, on the value and use of the latter. Biondo Flavio's relatively new understanding of the vernaculars as "rising from the ashes" of the Roman empire gave way to a campaign-mostly a Florentine effort-to promote the equality if not the superiority of modern languages over Latin. ${ }^{9}$

THE SPACE OF LANGUAGES IN EARLY QUATTROCENTO FLORENCE These different humanistic views of the nature and function of Latin and the vernacular of early Renaissance Florence have been closely discussed and analyzed by recent scholarship. ${ }^{10}$ Less frequently studied are the spaces in which Latin and the vernacular were used. In early modern Europe, "space" signified several different dimensions (public, quasi-public, private, and familial). Lefebvre's understanding of space is useful when thinking about what Bruni would have considered as the spaces occupied by Latin and vernacular: "the space of social practice, the space occupied by sensory phenomena, including products of the imagination such as projects and projections, symbols and utopias." 11 Bruni and his fellow humanists knew that the vernacular was the main language for communication in the "public space," which is meant here as areas that are open and accessible to the crowd, including sacred, civic, and semiprivate spaces such as courtyards and gardens. ${ }^{12}$ Instead, Latin occupied only a small portion of public spaces (official speeches, lectures, and formal political and cultural exchanges between international partners) and private spaces (published and manuscript texts). ${ }^{13}$ Bruni examined not solely the literary and textual interactions between the past and his present but also the way in which the oral and written modes of communication affected one another. This is because he necessarily would have been thinking of how to adapt Ciceronian treatises on oratory with practices of oral harangue of the 1400s. The

9. There is little room here for a summary of the differing views taken by humanists on the role of the vernacular across the quattrocento. See Rizzi's essay in this volume for more details on the 1435 debate. For a broader perspective, cf. Tavoni, Latino; Mazzocco, Linguistic Theories; and Coppini, "Il cielo." On the development of the vernaculars in early modern Europe, see Ann Moyer, "Vernacular Languages and Dialects," in Oxford Bibliographies, Renaissance and Reformation, http://www.oxford bibliographies.com/view/document/obo-9780195399301/obo-9780195399301-0010.xml.

10. See n. 6 .

11. See Henri Lefebvre, The Production of Space (Oxford, 1991), 11-12. See also Roger J. Crum and John T. Paoletti, Renaissance Florence: A Social History (New York, 2006), intro. and chaps. 1, 3, and 11; and Virginia Chieffo Raguin and Sarah Stanbury, Women's Space: Patronage, Place, and Gender in the Medieval Church (Albany, NY, 2005), 3-5.

12. Adam Jaworski and Crispin Thurlow, Semiotic Landscapes: Language, Image, Space; Advances in Sociolinguistics (London, 2010).

13. Lauro Martines, Power and Imagination: City-States in Renaissance Italy (London, 2002; 1st ed., 1979), 72-78. 
1435 debate over the languages spoken in ancient Rome was spurred, it is argued here, by the recent discoveries of Cicero's treaties on oratory and rhetoric and by the attempt to adapt quattrocento oratorical practices-in both Latin and the vernacular - to the classical models that were being studied and restored.

\section{ORALITY AND RHETORICAL EDUCATION}

Oratory was an indispensable tool for Renaissance intellectuals, politicians, and leaders. Because rhetorical training provided proficiency in writing and speaking, beginning in the late Middle Ages the production of manuals and commentaries on oratory grew immensely, to the extent that these texts rapidly became the bestsellers of Renaissance Italy. ${ }^{14}$ Rhetoric interested different classes of society and, inevitably, served different purposes: lawyers-in-training, scholars interested in classical Latin literature, and budding politicians all had reason to study treatises and commentaries on the art of oratory and epistolography (ars dictaminis). The verbal ceremonies of the urban communes of the Italian peninsula such as Florence (late thirteenth and early fourteenth centuries) distinguished Italian cities from other European communities and showed a deeply rooted awareness of the power of speech. ${ }^{15}$ Manuals on rhetoric offered active members of the Italian communes a set of skills indispensable for their political careers. The rapidly changing communities of late medieval Italy needed rhetoric in order to engage in the highly litigious and factious political arena. Furthermore, rhetoric needed to be made accessible to a society that was becoming more and more oriented toward the vernacular and the local as opposed to Latin and the supraregional. These two needs were met by Cicero's dialogic and dialectic art of speaking and writing and by vernacular adaptations by Brunetto Latini and Bono Giamboni of Cicero's De Inventione and the Rhetorica ad Herennium. ${ }^{16}$

14. For a survey of the reception and production of treaties of and manuals on rhetoric, see John Monfasani, "Humanism and Rhetoric," in Renaissance Humanism: Foundation, Forms, and Legacy, ed. Albert Rabil Jr. (Philadelphia, 1988), 171-235. On the tradition and reception of Ciceronian rhetoric, see Virginia Cox and John O. Ward, eds., The Rhetoric of Cicero in Its Medieval and Early Renaissance Commentary Tradition (Leiden, 2006). See Peter Mack, A History of Renaissance Rhetoric, 1380-1620 (Oxford, 2011), for a brief history of Renaissance rhetoric, and Stephen J. Milner, "Communication, Consensus and Conflict: Rhetorical Precepts, the Ars Concionandi, and Social Ordering in Late Medieval Italy," in Cox and Ward, Rhetoric, 365-408, for public speaking in communal Italy and the influence of Ciceronian texts.

15. See Witt, In the Footsteps; Craig Kallendorf, In Praise of Aeneas: Virgil and Epideictic Rhetoric in the Early Italian Renaissance (Hanover, NH, 1989); and James Hankins, ed., Renaissance Civic Humanism: Reappraisals and Reflections (Cambridge, 2000).

16. On the reception of Cicero's theories in late medieval Italy, see Cox and Ward, Rhetoric; Virginia Cox, "Ciceronian Rhetorical Theory in the Volgare: A Fourteenth-Century Text and Its Fifteenth-Century Readers," in Rhetoric and Renewal in the Latin West, 1100-1540: Essays in Honour 
The strong interest among humanists in the imitation and restoration of classical Latin instigated a separation between the study of rhetoric in Latin and the learning of vernacular oratory for political debate. ${ }^{17}$ Rather than trying to develop a more learned public harangue, humanism abandoned that arena. As a result, the use of Latin became for humanists a written and mostly semiprivate practice-with the exception of encomiastic speeches delivered before important guests and audiences. In other words, the humanists' emulation of classical texts took precedence over the modernization of ancient Latin rhetoric for sociopolitical purposes. Oratorical humanism took over the medieval ars dictaminis to the extent that the "restored" classical Latin became the lingua franca for literature, historiography, diplomacy, and political ritual. Meanwhile, localized and deliberative speaking was firmly in the hands of vernacular oratory, as discussed by Witt. ${ }^{18}$

Another important change in the study and practice of rhetoric at the turn of the fifteenth century was the stronger focus on the moral and intellectual formation of students, rather than the vocational training on public speaking offered by the medieval curriculum. This abstraction from the highly localized political and cultural contexts made it possible for Pierpaolo Vergerio the Elder and Leonardo Bruni to share ideas beyond the functional realm of rhetoric. The shift from the pragmatic use of rhetoric for political and forensic contexts in the late thirteenth and early fourteenth centuries to mostly epideictic rhetoric through the study and rewriting of ancient history can be seen from the following passage in Vergerio's De ingenuis moribus (1402): "Per philosophiam quidem possumus recte sentire quod est in omni re primum: per eloquentiam graviter ornateque dicere qua una re maxime conciliantur multitudinis animi; per historiam in utrumque iuvamur" (Through philosophy we can acquire correct views, which is of first importance in everything; through eloquence we can speak with weight and polish, which is the one skill that most effectively wins over the minds of the masses; but history helps us with both). ${ }^{19}$

Although he seems to indicate that public debate was possible, the limited freedom in Vergerio's Padua after the 1392 restoration of the Carrara rule meant that the only role oral eloquence could fill was celebratory: the arrival of an impor-

of John O. Ward, ed. Constant Mews, Cary J. Nederman, and Rodney M. Thomson (Turnhout, 2003), 201-26; and Milner, "Communication." See also Bono Giamboni, Fiore di rettorica, ed. Gian Battista Speroni (Pavia, 1994).

17. See Cox and Ward, Rhetoric, 125-33.

18. See Witt, In the Footsteps, chap. 8.

19. Kallendorf, Humanist, 48-49. 
tant ruler, festivities, university speeches, panegyrics, or invectives against the enemy become the most topical, morally charged, and highly emotive genres of quattrocento oratorical humanism. Even if Florentine humanists enjoyed more freedom than their fellow scholars in Padova, public speaking in Latin was eulogistic and self-promotional rather than republican and civic. This has been suggested recently by several scholars in their critique of Hans Baron's interpretation of Florentine civic humanism. ${ }^{20}$

In his essay on the linguistic debate of 1435, Andrea Rizzi argues that the real focus was the status and origin of the written Latin of fifteenth-century Italy. Yet behind Bruni's argument in the debate there was also an attempt to come to terms with the growing dominance of the vernacular in the oral realm-not just in everyday life but also in official and political communication. Humanistic debates about languages are thus perhaps best understood by considering literacy and orality as interacting and interrelated realms. ${ }^{21}$ Such interaction is shown eloquently and bilingually by the Florentine Agostino Vespucci in his 1501 letter to Niccolò Machiavelli, in which he describes the powerful performance of an unknown Roman orator:

Et veramente, Nicolò mio, qui è l'arte de l'oratore, perché costui è uno ignobile, et non più visto, né udito circulare o poco; et nondimeno per esser romano è piaciuto più che o il Fedra o il Marso o il Sabellico o el Lappo, che habentur optimi; et ha dimonstro havere auto in primis memoria grande, sapere bene distinguere et aperte narrare; monstrò quantum valeat pronuntiatio, quantum verborum copia et gestus, qui et ipsi voci consentit et animo, cum ea simul paret; ut equidem affirmare ausim, che spessissimo, non solum manus sed notus ipsius harì dimonstro alli auditori la sua volontà. ${ }^{22}$

20. See Hankins, Renaissance, for a survey of recent criticism of Baron's interpretation of Florentine quattrocento humanism.

21. See Mark Chinca and Christopher Young, Orality and Literacy in the Middle Ages: Essays on a Conjunction and Its Consequences in Honour of D. H. Green (Turnhout, 2005), 2-8. By "literacy" and "orality" is meant here the complex interplay between aural and written texts-such as speechesthat were destined for more than one audience or readership and were delivered in more than one format (i.e., read, spoken, and performed).

22. Niccolò Machiavelli, Opere, ed. Sergio Bertelli (Milan, 1982), 5:42. Incidentally, the Latin sentences are taken almost literally from Quintilian's Institutio Oratoria (XI, 65-66): "Quid autem quisque in dicendo postulet locus paulum differam, ut de gestu prius dicam, qui et ipse voci consentit et animo cum ea simul paret. Is quantum habeat in oratore momenti satis vel ex eo patet, quod pleraque etiam citra verba significat. Quippe non manus solum sed nutus etiam declarant nostram voluntatem." 
[And in truth, Niccolò, my friend, this was the art of the orator, because he is base-born and has never been seen before or heard about around here, or very little; and nevertheless, because he was a Roman, he gave more pleasure than Phaedra or Marso or Sabellico or Lippi, who are considered excellent. He showed, first of all, that he had a great memory, that he knows how to embellish well and to narrate clearly; he showed how good his pronunciation was, how good his vocabulary and gestures, which harmonized together with both his voice itself and his thoughts, since the former served the latter at the same time; so that truly I venture to affirm that, very often, not only with his hands but also with his very nods he would manifest his will to the audience. $]^{23}$

Vespucci's claims about the theatrical power of Latin in the oratorical performance were already recognized by Bruni in his writings about the relationship between Latin and the Florentine vernacular.

In short, Latin and vernacular were not in opposition or competition, they were "differently shimmering facets of the same unique jewel," as Celenza puts it. ${ }^{24}$ Such a revised understanding of the relationship between Latin and vernacular destabilizes the assumption that Latin humanism is an affair of elites. ${ }^{25}$ It also undoes the notion that vernacular and oral communication is culturally inferior or "low." Arguably, in the course of the 1435 debate, Latin humanists were attempting to come to terms with the dominance of the vernacular in the oral realm-especially in the context of official and political communication.

\section{LATIN AND VERNACULAR: THE DIALECTIC OF TRANSLATION}

Relatively unknown for his work on the interaction between Latin and vernacular right at the beginning of the fifteenth century is Antonio Loschi (1361-1441). A first-rate humanist, he produced a vernacular version of the pseudo-Quintilian Declamationes (1392), a rhetorical commentary of eleven orations by Cicero and several other essays and poetry in Latin. ${ }^{26}$ Loschi's vernacular text is a manifesto of the importance of volgarizzamenti at the turn of the fifteenth century:

23. Translation taken from James B. Atkinson and David Sices, eds., Machiavelli and His Friends: Their Personal Correspondence (DeKalb, IL, 1996), 41-42. Italics have been added.

24. Celenza, The Lost Renaissance, 144.

25. See Hankins, "Humanism," 24.

26. See Concetto Marchesi, "Il volgarizzamento italico delle 'Declamationes' pseudo-quintilianee [1907]," in Scritti minori di filologia e di letteratura (Florence, 1978), 2:447-72. On Loschi, see Paolo Viti, s.v. "Antonio Loschi," in Dizionario biografico degli Italiani (Rome, 1960-). 
Ma tra l'altre cose di che mi duole e increscie massimamente e cche a questo dire mi chiama si e che spessissimamente gli uomini del nostro tempo libri utilissimi e bellissimi di gramaticha anno tracti in volghare solo per la fama di quegli libri e dietro non molti anni non chonosciuto e non saputo chogliere il fructo d'essi i quali non sanza faticha e spesa e gratia avuti in tale lingua o sono serrati in tenebre o per fastidio d'ignoranza gienerato gittati come fangho tra vilissimi piedi.

[But I especially regret, amongst other things, that several men of our time very often translated the most useful and wonderful books from Latin into vernacular only because of the reputation of these works. A few years later, despite the hard work and costs and skills of the translators, these texts are-out of spite fuelled by ignorance-either hidden away or thrown out like mud on which the vilest feet have trampled. $]^{27}$

Loschi's translation and its preface show that a scholar of Latin did not shy away from the dissemination of classical knowledge in the volgare. Loschi lived and worked across two centuries and did not see the vernacular as inferior: his worry was that his translation would be "received poorly and despised as a lowly piece of work." ${ }^{28}$ As the current collection of essays demonstrates, major quattrocento humanists such as Bruni and Francesco Cattani da Diacceto as well as lesser-known scholars such as Antonio Colombella and Antonio di Lorenzo Ridolfi promoted and produced vernacular translation of a vast range of Latin texts.

Nevertheless, translating into the vernacular was sometimes opposed by scholars, especially when this practice involved technical texts. According to these critics, the vernacularization of philosophical or physiognomic texts required a proper vocabulary, which the vernacular language was allegedly not able to provide. What was seen as more troublesome was that translation could reveal truths that were meant to be kept secret and preserved from popular consumption. An interesting and paradoxical example of this hostility toward vernacularization is found in the Novellino, a collection of Tuscan short tales composed around 1280. Novella 78 describes a philosopher who most courteously undertook the translation of the sciences, "as a kindness to the gentry and other people." One night a vision came to him, where the goddesses of the sciences, in the guise of beautiful

27. Biblioteca Mediceo Laurenziana, Florence, ms. Martelli 4, 1r-v. For a list of testimonies of this work, see Marchesi, "Il volgarizzamento."

28. Marchesi, "Il volgarizzamento," (458): "ma perche sara auilito e comaltra bassissima cosa spregiato." 
women, were living in a brothel. He immediately woke up and realized that translating the sciences implied belittling the gods. For this reason he did not continue translating. Although expressing a strong view against the vernacularization of the sciences, the tale itself is paradoxically a vernacularization of a philosophical text since it is based on a passage from Macrobius's fifth-century commentary on the Dream of Scipio (I, 2, 17-19). The same passage was also adopted by Giovanni Boccaccio in his Genealogia deorum gentilium (III, preface, 3). ${ }^{29}$ As this example shows-as does Mellyn's essay on the translations of the Secretum-contaminations between "low" and "high" were common and encompassed a wide range of disciplines, including medicine, grammar, and philosophy.

Throughout the Middle Ages and early Renaissance, texts from these disciplines had been translated into the vernacular, selections that were based predominantly on the perceived needs of the readers. Ethical texts such as Boethius's De consolatione Philosophiae had wide circulation throughout the Middle Ages, as did medical texts or other philosophical works that offered concrete matters of interest. A cultivated if not professional reader would have been more interested in learning about civic virtue (to better participate in public life) and the pattern of the winds (in order to know whether his ships would safely cross the Mediterranean) rather than prime matter and generation, and Aristotelian treatises like Ethics and Meteorology were the first to be vernacularized. ${ }^{30}$

Although the translation into the volgare of technical texts raised anxieties and perplexities about the inadequacy of the unstable vernacular to express timeless truths, suitable rhetorical and philosophical strategies were elaborated to justify their vernacularizations. The opportunity of making knowledge available to a broader audience was the more usual justification. Translators of philosophical texts took advantage of Platonic and Aristotelian doctrines to defend their work: for instance, translators often refer to the doctrine of conventionality of languages, as Del Soldato shows in her essay on Diacceto. Between the fifteenth and sixteenth centuries, this became another powerful theoretical tool in the hands of the advocates of a noble use of the volgare. ${ }^{31}$ As Eugenio Refini argues in his

29. Henri Hauvette, Boccace: Étude biographique et littéraire (Paris 1914), 456; Roberto Crespo, "Da Macrobio al Novellino," Studi medievali 18 (1977): 227-30.

30. Noel H. Kaylor and Philip E. Phillips, eds., Companion to Boethius in the Middle Ages (Leiden, 2012); Chiara Crisciani, Michele Savonarola medico: Tra università e corte, tra latino e volgare, in Filosofia in volgare nel Medioevo; Atti del convegno, Lecce, 27-29 settembre 2002, ed. N. Bray and L. Sturlese (Leuvain la Neuve, 2003), 433-49, 436; S. Gentili, L'uomo aristotelico alle origini della letteratura italiana (Rome, 2005), 29-30.

31. Cesare Vasoli, "Su alcuni problemi e discussioni logiche del Cinquecento italiano," in Studi sulla cultura del Rinascimento (Manduria, 1968), 257-344; Eva Del Soldato, "An Aristotelian at the 
essay, by the end of the fifteenth century scholars legitimized their translations of technical texts not only through their paratexts but also in practice.

A century of transitions, interactions, and contaminations, the quattrocento paved the way for the official sanctioning of the volgare as a language of elevated discourse. With the triumph of the vernacular in the course of the next century, this legacy of the quattrocento was quickly forgotten. The following essays return our attention to the moment when, thanks to treatises, translations, and lively debates, the Latin language and the vernacular were first placed side by side and assessed both for what they could offer and for their limitations. ${ }^{32}$

Academy: Simone Porzio and the Problem of Philosophical Vulgarisation," in Bilingual Europe: Latin and Vernacular Cultures ca. 1300-1800, ed. Jan Bloemendal (Leiden, forthcoming). See also Del Soldato's article on Cattani da Diacceto in the current volume.

32. Mazzacurati, Il Rinascimento dei moderni. 